\title{
MLL/LPP Fusion Protein
}

National Cancer Institute

\section{Source}

National Cancer Institute. MLL/LPP Fusion Protein. NCI Thesaurus. Code C99330.

A fusion protein encoded by the MLL/LPP fusion gene. This protein is comprised of the $\mathrm{N}$-terminal half of the histone-lysine $\mathrm{N}$-methyltransferase MLL protein, including the AT hook DNA binding domain and the DNA methyltransferase domain, fused with the last 2 LIM domains of the lipoma-preferred partner protein. 